\title{
EDITORIAL
}

\section{Tatalaksana Infertilitas yang Rasional dan Efisien untuk Mempersingkat "Time to Pregnancy"}

\author{
Hartanto Bayuaji \\ Departemen Obstetri dan Ginekologi Fakultas Kedokteran Universitas Padjadjaran \\ Rumah Sakit Dr. Hasan Sadikin Bandung \\ Korespondensi: Hartanto Bayuaji, Email: tantobayuaji@gmail.com
}

\begin{abstract}
Abstrak
Tujuan: Memberikan pandangan kepentingan melakukan penatalaksanaan infertilitas yang efisien untuk mempersingkat time to pregnancy.

Metode: Telaah pustaka dan basis bukti.

Hasil: Kunci mempersingkat time to pregnancy pada penanganan infertilitas adalah melakukan work-up yang efisien dan rasional. Terdapat beberapa pemeriksaan yang mempunyai manfaat jelas berdasarkan basis bukti. Harihari tertentu pada siklus menstruasi seorang wanita dapat dimanfaatkan untuk melakukan beberapa pemeriksaan terpilih. Fokus pemeriksaan adalah identifikasi latar belakang kesehatan suami dan istri, mengetahui adanya ovulasi dan cadangan ovarium, tes patensi tuba, evaluasi anatomik uterus dan peritoneum, serta analisis sperma. Setelah data dasar tersebut diperoleh, dilakukan evaluasi komprehensif untuk mengetahui program penanganan yang sesuai. Saat ini telah terdapat panduan nasional praktik kedokteran penanganan infertilitas sebagai dasar untuk dapat menangani infertilitas secara efisien.

Kesimpulan: Time to pregnancy dapat dipersingkat dengan proses diagnostik dan penanganan yang berbasis bukti dengan memanfaatkan waktu-waktu tertentu dari siklus menstruasi.
\end{abstract}

Kata kunci: Infertilitas, time to pregnancy, penanganan infertilitas, rujukan

\section{Rational and Efficient Infertility Management Improve Shortening "Time to Pregnancy"}

\begin{abstract}
Objective: Provide an insight of the importance of conducting efficient and rational infertility management to shorten time to pregnancy.

Method: Literature and evidence base review.

Results: The key to shortening time to pregnancy in infertility management is to do an efficient and rational workup. There are several examination that have clear benefits. Certain days of a woman's menstrual cycle can be used to do some selected examinations. The focus of the examination is identification of the health background of husband and wife, ovulation documentation and ovarian reserve assay, tubal patency tests, anatomic evaluation of the uterus and peritoneum, and sperm analysis. After the basic data is obtained, a comprehensive evaluation is carried out to find out the appropriate management program. Currently there is a national guide to the practice of medical treatment of infertility as a basis for infertility management efficiently.

Conclusion: Time to pregnancy can be shortened by an evidence-based diagnostic and treatment process by utilizing certain times of the menstrual cycle.
\end{abstract}

Key words: Infertility, time to pregnancy, infertility management, referral system. 


\section{Pendahuluan}

Infertilitas adalah tidak terjadinya kehamilan setelah periode satu tahun dengan hubungan seksual teratur tanpa kontrasepsi. Masalah ini terjadi pada sekitar $15 \%$ pasangan suami istri usia reproduktif. ${ }^{1-3}$ Walaupun infertilitas merupakan masalah penting dalam kesehatan reproduksi, sering ditemukan hambatan dalam talaksananya. Hal ini disebabkan beragamnya etiologi yang mendasari maupun modalitas pemeriksaan yang tersedia. Beragamnya tingkat pemahaman pengelola kesehatan tentang masalah ini menyebabkan risiko penanganan menjadi berlarutlarut. Dampak dari hal ini adalah berkurangnya potensi fertilitas seorang wanita akibat lamanya proses penanganan. Terdapat konsep time to pregnancy, yaitu waktu yang dibutuhkan untuk didapatkannya kelahiran hidup dari mulai masalah infertilitas ditegakkan. ${ }^{4,5}$ Time to pregnancy akan dapat memanjang bila penatalaksanaan infertilitas tidak dilakukan secara efisien dan rasional. Beberapa hal akan dibahas dalam tulisan ini sebagai upaya untuk mempersingkat time to pregnancy pada penatalaksanaan infertilitas.

\section{Langkah Pertama: Back To Basic}

Seperti telah disebutkan bahwa terdapat beragam etiologi infertilitas, sehingga dengan sendirinya pemahaman patofisiologi menjadi beragam serta pemeriksaan yang dibutuhkan menjadi bertambah. Walaupun demikian, secara praktis fokus penatalaksanaan dapat diarahkan pada beberapa hal agar lebih efektif dan efisien. Beberapa hal tersebut adalah sebagai berikut: ${ }^{6}$

1. Pahami proses terjadinya kehamilan secara benar

Pemahaman yang cukup pada dasar-dasar terjadinya kehamilan secara alami. Seperti diketahui agar terjadi kehamilan dibutuhkan: sperma yang memenuhi syarat, kavum uteri normal, tuba paten, dan ovulasi yang konsisten. Pengalaman klinis menunjukkan hal-hal tersebut dirasakan cukup untuk memperkirakan faktor mana yang merupakan penyebab kelainan infertilitas.

2. Pemeriksaan dasar fokus pada hal-hal berikut: ${ }^{1,7}$

a. Adanya gangguan ovulasi yang biasanya ditandai dengan oligo atau amenore

b. Dugaan gangguan patensi tuba, kelainan anatomis uterus, dan atau endometriosis.

c. Terdapat dugaan penyebab faktor pria.

3. Manfaatkan hari-hari tertentu pada siklus menstruasi secara efisien.

Proses diagnostik infertilitas dimulai dari anamnesis. Anamnesis infertilitas memerlukan waktu yang cukup agar tergali beberapa aspek penting yang mungkin menjadi etiologi. Selain itu dengan waktu yang cukup juga memungkinkan memberikan konseling pada pasangan. Informasi yang cukup diharapkan dapat meningkatkan kepatuhan pasangan untuk menjalani penatalaksanaan infertilitas menjadi lebih optimal.

Anamnesis perlu menggali hal-hal sebagai berikut: lama infertilitas, hasil-hasil penanganan yang mungkin pernah dijalani sebelumnya, karakteristik siklus haid, riwayat obstetri, riwayat kontrasepsi sebelumnya, frekuensi koitus dan riwayat disfungsi seksual, riwayat pembedahan sebelumnya, kelainan tiroid, galaktore, hirsutisme, nyeri panggul atau dispareunia, obat-obatan yang tengah digunakan atau riwayat alergi, riwayat keluarga dengan kelainan kongenital, retardasi mental, menopause dini, atau kegagalan fungsi reproduktif lain, kemungkinan paparan 
zat berbahaya seperti toksin atau radiasi, dan. penggunaan tembakau atau narkoba. Pemeriksaan fisik perlu mencari hal-hal yang terkait patologi sistem reproduksi maupun kelainan sistemik yang berpotensi mengganggu fertilitas. ${ }^{1,6}$

Pemeriksaan penunjang, diharapkan dapat dilakukan secara efisien pada waktu yang tepat. Perlu diperhatikan kaitan pemeriksaan dengan siklus menstruasi, karena beberapa pemeriksaan hanya dapat dilakukan pada hari-hari tertentu siklus menstruasi. Memanfaatkan hari-hari tertentu pada siklus menstruasi ternyata dapat mempersingkat waktu yang dibutuhkan untuk memperoleh data awal. Sangat ideal apabila pasien dapat berkunjung pertama kali pada hari awal menstruasi. Secara lebih terperinci, hal tersebut dapat dilihat pada uraian berikut:

a. Hari kedua/ketiga siklus menstruasi: periode ini merupakan saat untuk melakukan pemeriksaan ultrasonografi transvaginal guna mengevaluasi anatomi uterus dan ovarium. Penghitungan folikel antral juga dilakukan pada saat ini. Demikian pula, endometrium pada saat ini harus terlihat tipis, yang menandakan rendahnya kadar estrogen di awal siklus. Selain itu periode ini merupakan waktu yang tepat untuk melakukan pemeriksaan hormonal (kadar FSH, LH, estradiol, prolaktin). Hasil dari pemeriksaan hormonal tersebut digunakan untuk mengevaluasi faktor ovulasi. Dalam kunjungan ini direncanakan pula untuk melakukan analisis semen.

b. Hari ke-9/10/11: periode ini merupakan saat yang optimal untuk melakukan evaluasi patensi tuba, baik secara radiologis maupun ultrasonografis. Selain itu dapat pula dilakukan analisis semen apabila suami telah mendapat penjelasan yang cukup dalam kunjungan sebelumnya.

\section{Langkah Kedua: Pilih Pemeriksaan Spesifik yang Efisien}

Bila telah didapatkan perkiraan kondisi patologi yang ada, maka langkah berikutnya adalah memilih pemeriksaan lanjutan yang sesuai. Pada tahap ini dapat timbul masalah mengingat banyaknya modalitas pemeriksaan yang tersedia. Walaupun demikian terdapat berbagai basis bukti (evidence) yang dapat digunakan sebagai dasar memilih pemeriksaan yang paling efisien.

\section{A. Gangguan Ovulasi}

Gangguan ovulasi merupakan penyebab sekitar 40\% infertilitas pada wanita. Gejala klinik yang tampak dapat berupa gangguan menstruasi. Walaupun demikian pada beberapa kondisi kelainan menstruasi tidak tampak jelas secara klinis. Riwayat menstruasi merupakan hal penting. Siklus menstruasi yang normal berkisar antara 25-35 hari, dengan karakteristik perdarahan yang konsisten. Bila siklus haid tidak teratur, biasanya diagnosis anovulasi dapat ditegakkan dengan baik. Sebaliknya bila siklus teratur, maka adanya ovulasi harus dibuktikan dengan menggunakan beberapa cara seperti pengukuran suhu basal badan, pengukuran kadar progesterone serum, deteksi lonjakan LH, dan ultrasonografi transvaginal serial. ${ }^{1}$

Di samping mengetahui adanya anovulasi, salah satu pemeriksaan yang penting adalah penilaian cadangan ovarium. Cadangan ovarium merupakan gambaran potensi fertilitas yang dilihat dari jumlah oosit yang masih tersedia. Pemeriksaan ini dilakukan secara selektif pada beberapa golongan berikut: usia di atas 35 tahun, riwayat keluarga dengan menopause dini, pernah menjalani operasi pada satu atau kedua ovarium, pernah menjalani kemoterapi atau radioterapi pelvis, mengalami infertilitas yang tak terjelaskan 
(unexplained infertility), respon yang buruk terhadap stimulasi ovarium sebelumnya, dan rencana mengikuti program teknologi reproduksi berbantu. Beberapa tes yang dapat dilakukan adalah: ${ }^{1,6,7}$ kadar FSH dan estradiol hari ke-3, hitung folikel antral (antral follicle count), dan kadar Anti Mullerian Hormone (AMH). Beberapa ulasan menunjukan bahwa ketiga teknik di atas termasuk dapat diterapkan secara klinis dan memiliki kemampuan diagnostik yang cukup baik.

B. Gangguan Patensi Tuba

Gangguan patensi tuba menjadi penyebab dari sekitar 30\% infertilitas wanita, oleh karena itu evaluasi faktor ini merupakan hal penting. Pemeriksaan yang dapat dilakukan antara lain: ${ }^{1,8}$

- Histerosalpingografi (HSG): dapat digunakan untuk mendeteksi sumbatan tuba proksimal maupun distal, adanya salpingitis ismika nodosa, adhesi perituba, serta hidrosalping. Nilai prediksi positif HSG adalah sekitar 38\% sementara nilai prediksi negatifnya sekitar $94 \%$. Hal ini berarti bila hasil HSG menunjukkan tuba paten, maka hasil tersebut dapat dipercaya dengan cukup baik. Sebaliknya bila hasil HSG menunjukkan adanya obstruksi tuba, maka diperlukan evaluasi lanjut untuk mengkonfirmasi hal tersebut.

- Sonohisterosalpingografi: teknik ini hampir serupa dengan histerosalpingografi menggunakan sinar $\mathrm{X}$, namun aliran cairan dalam tuba diikuti menggunakan ultrasonografi Doppler transvaginal. Kadang ditemukan kesulitan untuk mengidentifikasi tuba mana yang paten. Dengan demikian bila didapatkan adanya koleksi cairan di kavum Douglas pasca tindakan maka disimpulkan salah satu tuba adalah paten.

- $\quad$ Kromotubasi laparoskopi: merupakan baku emas untuk penilaian patensi tuba. Teknik ini dilakukan bila ditemukan dugaan obstruksi tuba dari hasil HSG atau sonohisterosalpingografi. Walaupun merupakan baku emas, teknik ini merupakan teknik operatif. Dengan demikian dapat timbul potensi penyulit dari teknik operasi maupun anestesinya.

\section{Kelainan Uterus}

Kelainan uterus sebagai penyebab infertilitas difokuskan pada kemungkinan terjadinya gangguan pada proses fertilisasi dan implantasi. Dalam hal ini integritas kavum uteri berperan penting. Beberapa penyebab infertilitas akibat kelainan uterus antara lain kelainan kongenital (uterus unikornis, bikornis, atau septatus), maupun kelainan didapat (polip endometrium, mioma submukosa, atau sinekia uteri). Untuk mengetahui adanya kelainan tersebut, dapat dipilih beberapa teknik pemeriksaan yaitu: ${ }^{6}$

- Histerosalpingografi (HSG): merupakan teknik yang telah lama digunakan. Walaupun demikian, teknik ini mempunyai sensitivitas dan nilai prediksi positif yang rendah (50\% dan 30\%) untuk mendeteksi kelainan yang sering terjadi seperti polip endometrium serta mioma submukosa.

- Ultrasonografi transvaginal dan sonohisterosalpingografi: dengan menggunakan teknik sonohisterosalpingografi dapat diperoleh pencitraan yang lebih baik dari kavum uteri. Teknik sonohisterosalpingografi mempunyai nilai prediksi positif yang tinggi (sekitar 90\%) untuk mendeteksi kelainan seperti polip endometrium, 
mioma submukosa, dan sinekia uteri.

- $\quad$ Histeroskopi: merupakan metode definitif pemeriksaan kavum uteri. Walaupun demikian aplikasinya terkendala ketersediaan peralatan dan biaya pemeriksaan yang masih tinggi.

\section{Kelainan Sperma}

Sama halnya dengan pemeriksaan pada wanita, pemeriksaan pada pria juga diawali dengan investigasi mengenai karakteristik hubungan seksual, lama infertilitas, penyakit yang pernah dialami, kondisi medis sistemik saat ini, riwayat pembedahan sebelumnya, obat yang digunakan dan riwayat alergi, riwayat penyakit menular seksual, dan paparan zat yang toksik terhadap gonad. Analisis semen harus dilakukan sejak awal dan tidak menunggu pemeriksaan faktor wanita selesai. Hal ini karena faktor pria merupakan penyebab dari sekitar 30-40\% infertilitas. ${ }^{69}$ Dalam menginterpretasi hasil analisis semen diperlukan kehati-hatian. Bila hasil analisis semen abnormal, dianjurkan untuk mengidentifikasi faktor yang mungkin dapat dikoreksi seperti gaya hidup sebelum melakukan analisis ulang. Analisis ulang dapat dilakukan sekitar 2 bulan kemudian. Dalam satu penelitian ditemukan bahwa subfertilitas pria diprediksi terjadi apabila didapat konsentrasi sperma kurang dari 13,5 juta/mL, motilitas kurang dari 32\%, dan morfologi normal kurang dari $9 \% .^{10}$

\section{Langkah Ketiga: Analisis Komprehensif Semua Data yang Terkumpul}

Setelah hasil-hasil pemeriksaan terkumpul, maka dilakukan analisis komprehensif. Tergantung dari kesimpulan yang didapat, penatalaksanaan dapat berupa induksi ovulasi pada anovulasi, koreksi kelainan anatomik pada uterus maupun tuba, koreksi kelainan yang dapat diubah (modifiable) pada kelainan sperma, aplikasi teknologi reproduksi berbantu (assisted reproductive technology). ${ }^{11}$

\section{Langkah Keempat: Ketahui Saat Merujuk yang Tepat}

Mengetahui saat yang tepat merujuk pasangan dapat membantu meningkatkan keberhasilan penanganan. Tidak dapat dipungkiri bahwa tidak semua tempat pelayanan kesehatan reproduksi memiliki sarana yang memadai untuk menangani infertilitas hingga tahap teknologi reproduksi berbantu. Walaupun demikian, hampir di tiap propinsi talah berdiri pusat-pusat pelayanan tersebut sehingga yang harus dioptimalkan adalah kemitraan dengan sejawat yang bertugas di daerah. Beberapa tindakan seperti investigasi dasar, induksi ovulasi sederhana, bahkan inseminasi intrauterin memungkinkan untuk dilakukan di tempat praktik. Beberapa jenis kasus yang membutuhkan rujukan segera antara lain azoospermia, obstruksi tuba bilateral, periode infertilitas yang terlalu lama dan usia wanita 23-39 tahun. ${ }^{11}$

Dari pemaparan ini dapat disimpulkan bahwa mempersingkat time to pregnancy pada penanganan infertilitas tergantung pada pemilihan waktu dan jenis pemeriksaan yang tepat, mengidentifikasi kemampuan penanganan oleh klinisi, dan melakukan proses rujukan yang optimal. Diharapkan dengan pemahaman ini, tidak hanya keberhasilan proses reproduksi yang menjadi tujuan namun juga kualitas individu yang dihasilkan melalui penatalaksanaan ini. 


\section{Daftar Pustaka}

1. Practice Committee of the American Society for Reproductive M. Diagnostic evaluation of the infertile female: a committee opinion. Fertil Steril. 2015;103(6):e44-50.

2. Zegers-Hochschild F, Adamson GD, Dyer S, Racowsky C, de Mouzon J, Sokol R, et al. The International Glossary on Infertility and Fertility Care, 2017. Fertil Steril. 2017;108(3):393-406.

3. American College of $\mathrm{O}$, Gynecologists Committee on Gynecologic P, Practice C. Female age-related fertility decline. Committee Opinion No. 589. Fertil Steril. 2014;101(3):633-4.

4. Sozou PD, Hartshorne GM. Time to pregnancy: a computational method for using the duration of non-conception for predicting conception. PLoS One. 2012;7(10):e46544.

5. Cooney MA, Buck Louis GM, Sundaram R, McGuiness BM, Lynch CD. Validity of self-reported time to pregnancy. Epidemiology. 2009;20(1):56-9.

6. Balen AH. Infertility in Practice. edition 4. Boca Raton, Florida, USA: CRC Press Taylor \& Francis Group; 2014.
7. Practice Committee of the American Society for Reproductive M. Testing and interpreting measures of ovarian reserve: a committee opinion. Fertil Steril. 2015;103(3):e9-e17.

8. Saunders RD, Shwayder JM, Nakajima ST. Current methods of tubal patency assessment. Fertil Steril. 2011;95(7):21719.

9. Practice Committee of the American Society for Reproductive M. Diagnostic evaluation of the infertile male: a committee opinion. Fertil Steril. 2015;103(3):e1825.

10. Guzick DS, Overstreet JW, Factor-Litvak P, Brazil CK, Nakajima ST, Coutifaris C, et al. Sperm morphology, motility, and concentration in fertile and infertile men. N Engl J Med. 2001;345(19):1388-93.

11. Himpunan Endokrinologi Reproduksi dan Fertilitas Indonesia, Perhimpunan Fertilisasi In Vitro Indonesia, Ikatan Ahli Urologi Indonesia, Perkumpulan Obstetri \& Ginekologi Indonesia. Konsensus Penanganan Infertilitas.Jakarta. 2013. 